\title{
Value Co-Creation in Ecotourism: Finding Solutions in a Digital Era
}

Laura Hernández-López

laurahlz@gmail.com

University of Granada, Spain

Salvador Del Barrio-García

dbarrio@ugr.es

University of Granada, Spain

\begin{abstract}
This study aims to identify the main actors in the ecotourism online value co-creation ecosystem. With the ever-increasing demand to which the ecotourism sector has been subject in recent years, there is a need for business models featuring interactive tools that allow ecotourists to participate and co-create their own experiences. Not only will ecotourism businesses and ecotourists participate in this process, but so too will several other stakeholders, becoming key actors in the co-creation of value.
\end{abstract}

Ecotourism, being of a hedonic and experiential nature, requires strategies that are geared towards enjoyment of the joint value co-creation experience. With this finality, we present some factors, such as motivation, that are necessary for the ecotourist's value co-creation, as well as various other aspects that influence their behavior.

Our expectation is that value co-creation will have a positive effect on the behavior and experiences of tourists when it comes to developing ecotourism products and services. Specifically, we expect that the implementation of a co-creation strategy will lead to greater satisfaction and loyalty. Accordingly, drawing on the existing literature, we present a theoretical proposal of the antecedents and consequents that affect and enable online value co-creation by ecotourists.

Keywords: Value co-creation, ecotourism, social networking sites, virtual platforms, satisfaction, loyalty. 
Hernández-López, L. \& Del Barrio-García, S. (2018). Value Co-Creation in Ecotourism: Seeking Joint Solutions in a Digital Era, 2008-2014. Journal of Business, Universidad del Pacífico (Lima, Peru) Vol.10 (1): 38-51

\section{Introduction}

Ecotourism, according to Turismo: Panorama 2020, published by the World Tourism Organization, is the segment of the tourism sector that has grown the most in recent years. Travelers, just like most of the public at large, are becoming increasingly environmentally aware. Ecotourism grew exponentially in the eighties just as tourism was being transformed into a mass market, serving as the antidote to the explosion of tourist resorts extending across much of Europe and the Americas. And so it was that the pristine and the prolific was turned into a tourist attraction (Mack, 2011).

This trend, representing a popular approach to vacationing without leaving a footprint or a social or cultural impact, is still on the increase, having expanded particularly rapidly in tourist markets such as Latin America and South Africa, while also dominating the sector in the likes of Kenya or Costa Rica (OMT, 2002), even if it is recognized that not all visitors can be wholly classed as ecotourists.

One of the most accepted definitions is that of Ceballos-Lascurain (1987), who characterizes ecotourism as:

"That form of environmentally responsible tourism that involves travel and visitation to relatively undisturbed natural areas with the object of enjoying, admiring, and studying the nature (the scenery, wild plants and animals) [...] through a process which promotes conservation, has a low impact on the environment and on culture and favors the active and socioeconomically beneficial involvement of local communities"

Hence, we refer in this study to ecotourism consumers as "ecotourists" in line with Sarkar et al. (2013) who describe them as "anyone travelling with the primary motivation of viewing, enjoying and experiencing nature in a relatively undisturbed and uncontaminated natural area and undertaking at least one ecotourism experience during their trips". Ecotourists are motivated by the prospect of experiencing peace and quiet in a natural environment, being close to nature, learning about the natural environment, acquiring new emotional and adventurous experiences, and selfdiscovery (Weaver \& Lawton, 2002).

However, it is important to consider the following questions: What developments will be seen in ecotourism in the coming years? How do we value ecotourism assets? What are the benefits of co-creating value in the ecotourism sector? What factors influence consumer behavior when co-creating value in ecotourism services? Where exactly will future investments in the sector be made?

In this context of innovation, growth, and evolution in the ecotourism sector, the concept of value co-creation (VCC) in which businesses need to interact, dialogue, coproduce, and generate content alongside their customers takes on considerable importance (Prahalad \& Ramaswamy, 2004; Füller, 2010; Hoyer, et al., 2010). In past decades, travel planning was not quite so straight-forward, involving guides, maps, or books for certain destinations, but modern technologies are giving rise to different tourist activities, and with them, new types of tourist experiences (Neuhofer, Buhalis \& Ladkin, 2014). 
This is a pressing issue for the ecotourism sector, as ecotourists are not exempt from ICT implementation; rather, they are increasingly immersed in it, seeking out new destinations that are compatible with their interests and where they can disconnect from their routine. As such, the value co-creation by ecotourists on social media ought to be considered important for the ecotourism sector.

In this study, we seek to explore the main contributions of the value co-creation context and ecosystem for ecotourism, examining a series of antecedents and consequences of $\mathrm{VCC}$ regarding this market segment.

\section{Value co-creation in ecotourism}

\section{Importance and context of value co-creation in ecotourism}

Grissemann \& Stokburger-Sauerc (2012) note that the concept of co-creation is particularly important to the context of tourism as a means of giving customers memorable and original experiences, and is thus vital in allowing providers to leverage competitive advantages. Technology-driven value co-creation in ecotourism constitutes a framework of interest for tourism research. However, few research along these lines has yet been done for the field of ecotourism.

There have been some studies on experiential value co-creation alongside ecotourism tour guides (Awuor et al., 2015), and on the effects of value co-creation on ecotourism's brand image (Revilla et al., 2016). Moreover, we have identified some studies on ecotourism value co-creation on social networking sites, which includes content generation by travelers on platforms like TripAdvisor about stays at ecolodges (Lu \& Stepchenkova, 2012); co-creative behavior and social interactions among ecotourists in virtual communities (Chuang et al., 2013; Sarkar et al., 2015), as well as drivers to the socialization and exchange of knowledge by ecotourists using social networking sites (Sarkar et al., 2013).

However, there is a need for further research about consumer value co-creation on virtual ecotourist platforms, now that travelers are empowered to become increasingly participative actors in commercial transactions (Sigala, 2015). That is, ecotourists have not stopped at reviewing information or sharing comments online, but trade or market their own products or services and request offerings tailored to their needs (Agrawal \& Rahman, 2015)

Thus, more than simply finding out about consumers' opinions, desires, and needs, the novel aspect of virtual co-creation lies in utilizing their skills and creative input to solve problems; indeed, it is in this sense that they assume to role of co-creators (Füller, 2010). Has been shown that users wish to share information (Füller et al., 2010) and take part in innovative projects (Zwass, 2010), so value is therefore created by customers through their everyday practices; as such, there is a need for the ongoing study of these activities so as to develop value-added, service-oriented strategies. In this regard, Grönroos (2008) stated that if a business proposes and provides value to customers, as well as making its goods or services accessible and interacting with customers, it will be thinking, planning, and acting like a service provider. 
In the case of tourism organizations, Tussyadiah et al., (2013) propose that successful co-creation depends on their absorptive capacity in identifying, locating, and empower tourists with the skills and characteristics necessary to become collaborators. Thus, tourism businesses have the opportunity to set up platforms on which to develop a tailored, context-sensitive, and co-created offering (Oliveira \& Panyik, 2014).

Although co-creation and technology can enhance competition, research in this field remains very limited, especially in terms of the value co-creation, technologies, and experiences related to tourism (Von Solms \& Von Solms, 2016). More specifically, in ecotourism few studies have been carried out.

\section{Ecotourism consumers, co-creating their experiences}

Consumers can influence the value co-creation process, compete with companies in extracting value, and partner with them (Tussyadiah, I., \& Zach, 2013); that is, as well as contributing through the expression of desires and needs, they get involved by offering their knowledge, skills, and resources. Sarkar et al. (2013) show that ecotourists looking for opportunities to learn and generate knowledge, as well as to socialize experiences with their peers. To open up a dialogue with ecotourists, there is a need for ecotourism organizations to provide platforms that foster intense interaction between participants and formation of the relationships required to build a community (Füller, 2010). Moreover, those ecotourists who engage heavily with social networking sites will be more motivated to use it as a key channel for participating and codesigning products and/or services (Cheung \& To, 2016).

According to Yadav et al. (2016), a few reasons why customers co-create include customizing their products, accessing services, gaining prestige in the community, money rewards, and enjoyment. Cheung \& To (2016) argue that when consumers develop a stronger intention to co-create, they lend impetus to the co-creation process by sharing information and knowledge or providing feedback on service innovation, thus increasing the level or degree of customer co-creation.

Thus, in the ecotourism value co-creation system (Fig. 1) tourists looking for and gather information before traveling (Frias-Jamilena, Polo-Peña, \& Rodríguez-Molina, 2016); during the trip they can keep looking for and collecting additional information about the destination (Amaral, Tiago, \& Tiago, 2014), and then, after the trip, they exchange knowledge and recommendations, respond to other comments, and express willingness to help (Yi \& Gong, 2013).

\section{Necessary tools for co-creating value in virtual ecotourism environments}

Technology has a great influence on tourism experience networks, subjecting them to constant change (Binkhorst, 2008). For this reason, consumers require toolkits comprised of blogs, platforms, (fig.1), spaces for joint collaboration, and user designs that let them create solutions and transfer knowledge readily (Füller, 2010). 
As well as being useful co-creation tools, the technological mechanisms with which customers publish their opinions and comments also become important sources of marketing information (Grissemann \& Stokburger-Sauer, 2012). Therefore, two-way communication platforms between users play an ever-more important role in facilitating word-of-mouth exchanges between ecotourists, a form of socialization that can lead in turn to knowledge sharing (Sarkar et al., 2013).

Technology is used for tourists to co-create value with companies and other users; thus, tourists feel greater commitment to technologies and platforms, because they enrich their physical experience (Neuhofer et al., 2014). Social networking sites are online platforms that ecotourism destinations and ecotourism operators can use to improve social interactions, with the potential for sharing knowledge and improving consumers' ecotourism experiences (Sarkar et al., 2015).

Both ecotourism businesses and other stakeholders are required to make use of virtual toolkits (Fig. 1); once consumers leave their fingerprint by adding content to the platform, they become curious about how other users react to their posts. Moreover, they wish to be kept informed about the latest visitors, comments, and evaluations (Füller, 2010). At the same time, it is vital that these are platforms of empowerment, availing users of greater access and participation in the value creation process alongside tourism organizations (Tussyadiah \& Zach, 2013), so that consumers retain their belief in the community's value.

\section{Ecotourism businesses and stakeholders, co-creating value in the design of virtual tools}

In this section, we begin by posing the following question: To what extent have ecotourism businesses and stakeholders been involved in designing virtual tools for VCC alongside customers? There is no easy answer to this question, since not all ecotourism businesses utilize ICT, and managers do not always have access to or knowledge of such technology. However, they are not the only ones responsible for managing value among ecotourists; other stakeholders (tour operators, governments, private institutions, associations, etc.) are also becoming increasingly involved in creating content related to ecotourism or natural destinations.

Tussyadiah et al., (2013) argue that for tourism organizations, successful co-creation depends on their capacity to identify, locate, and empower tourists with the skills and characteristics necessary to become collaborators (Fig. 1). Thus, ecotourism businesses and tour operators need to encourage ecotourists to improve dialogue and exchange content through their websites and social networking sites profiles (Sarkar \& Law, 2015).

According to Piller \& Gülpen (2016), the main aim of a business engaged in co-creation is to increase their information base about joint solution needs, applications and technologies. To achieve this aim, the business has to implement participative strategies, opinion platforms, and user and community innovation tools for customer co-creation. 
The ecotourism value co-creation ecosystem is represented in Figure 1 . The model includes only actors and components specific to co-creation.

Figure 1 Value co-creation ecosystem in ecotourism

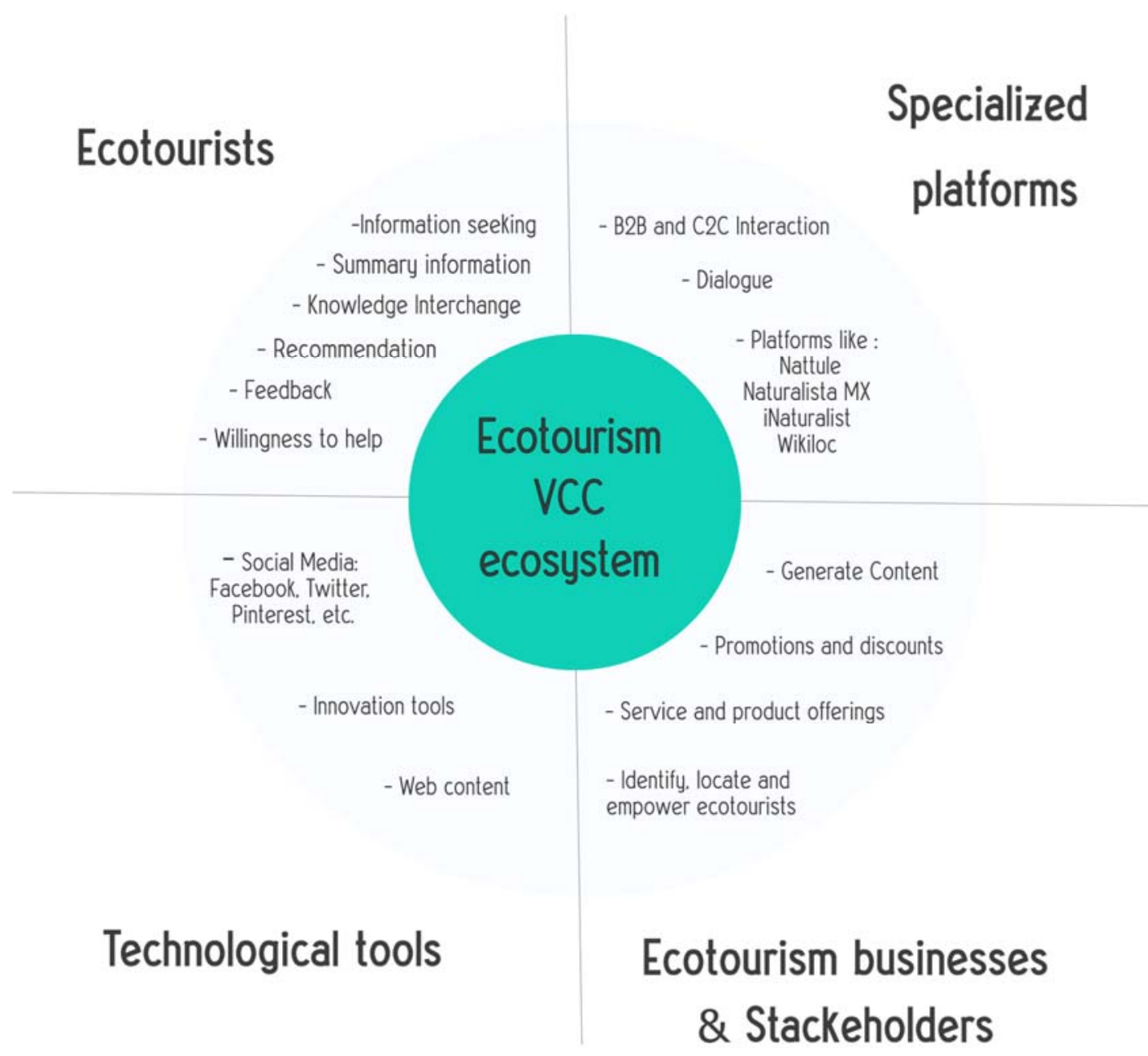

Source: Own

\section{Antecedents and consequences of value co-creation in virtual ecotourism environments}

Value co-creation in the business sector has been studied by various authors who address the importance of the concept and the evolution of new markets (Cova \& Salle, 2008; Gronroos, 2000; Hoyer et al., 2010; Orcik et al., 2014; Prahalad \& Ramaswamy, 2000, 2004b; Ramaswamy, 2009; Randall et al., 2011; Yi \& Gong, 2013).

The literature on value co-creation in tourism has yielded interesting research lines, such as the role of the consumer in co-creating tourism experiences, trips, vacations and entertainment (Binkhorst, 2008; Prebensen \& Foss, 2011; Bharwani \& Jauhari, 2013; Sfandla, 2013; Piller \& Gülpen, 2016); customer satisfaction and loyalty as drivers of co-creation with travel agencies (Grissemann \& Stokburger-Sauer, 2012); 
and the antecedents and consequences of the co-creation experience (Prebensen, Woo, \& Uysal, 2013).

VCC has emerged as a result of the ubiquity and accessibility of ICT in its multiple aspects. Drawing on this literature review, in this study we propose a theoretical model to explore online value co-creation by ecotourists, as shown in Figure 2, focusing on antecedents such as motivation and technical support experiences - the dimensions explored in two primary studies (Yi \& Gong, 2013; Agrawal \& Rahman, 2017) - as well as consequences such as satisfaction with the business, satisfaction with one's own performance, and loyalty.

\section{Antecedents and dimensions of VCC in ecotourism}

From the standpoint of Prebensen et al. (2013), both customer motivation and participation are vital antecedents for the development of value co-creation. These authors find that motivation has a positive influence on the participation of tourists. Other authors agree that virtual VCC is a combination of multiple intrinsic and extrinsic motives that compel users to participate in co-creation activities (Füller, 2010; Constantinides et al., 2015). According to Zwass (2010) potential motivators of cocreation include learning, altruism, recognition, money rewards, gamification, and enjoyment, among others.

The structures and incentives for multiple actors to participate and share value are necessary for sustaining value co-creation (Cabiddu, Lui, \& Piccoli, 2013). For example, Sarkar et al. (2015) discover that ecotourists are motivated by the acquisition and exchange of knowledge in relation to ecological matters, as part of their learning and educational experience on ecotourism.

However, it should be taken into account that motivation is not a unidimensional construct but varies in terms of level and orientation (Grissemann \& Stokburger-Sauer, 2012). These authors take into account certain intrinsic and extrinsic motivators that drive participation on virtual VCC platforms, such as financial rewards. Along similar lines, Füller (2010) observes that reward-oriented consumers are highly motivated to participate in virtual co-creation, and incentives can encourage consumers to make more and better contributions or attract others with an interest. Moreover, he finds that businesses tend to offer prizes and rewards only to those customers who present the best innovative ideas (Yadav et al., 2016). In general, money rewards are included in co-creation projects in virtual environments.

On the other hand, few authors have focused on gamification as a motivator in value co-creation. Neuhofer et al. (2014) propose that games provide a range of innovative technologies that promote greater technological adoption in the creation and improvement of experiences. They note that TripAdvisor has developed gamification apps to motivate and inspire travelers to contribute content by sharing travel resources with others (Yoo et al., 2016).

Enjoyment is included in the study as an important motivator in the context of travel because travelers seek pleasure, engaging in activities for enjoyment, entertainment, and fun (Jeong \& Jang, 2011). According to Zwass (2010), enjoyment constitutes a state of fluidity and joy, and is one of the essential motivators of participants in virtual worlds. Füller et al. (2010) explore the sphere of product development, discovering that enjoyment motivates members of the online community to contribute to joint innovation activities, and that consumer enjoyment can strengthen the feeling of active participation. This theoretical study includes "experienced tool support" as a variable, 
exploring Füller et al. (2010) and which makes reference to how consumers feel about interaction tools that allow them to participate actively in virtual co-creation. The authors conclude that tool support has a positive effect in the enjoyment experienced. As far as the dimensionality of customer value co-creation is concerned, some authors have analyzed its composition (Gummesson \& Mele, 2010; Randall et al., 2011; Cossío-Silva et al., 2016). The findings in the literature support the notion that value cocreation is a multidimensional construct ( $\mathrm{Ng}$ et al., 2010; Yi \& Gong, 2013; Ranjan \& Read, 2016; Agrawal \& Rahman, 2017).

Yi \& Gong (2013) indicate that costumer VCC has two overarching dimensions, each in turn comprised of multiple components. The first dimension of customer participation includes components such as information seeking, information sharing, responsible behavior, or personal interaction. In turn, the second dimension, customer citizenship behavior, is determined by feedback, advocacy, helping, and tolerance. Cossío-Silva et al. (2016) note that the first dimension refers to customer behavior during service provision, considered necessary to achieve an adequate performance level during value co-creation. The second refers to a type of behavior that can add value to an organization, but which is not necessary for co-creating value (Cossío-Silva et al., 2016).

Meanwhile, Agrawal \& Rahman (2017) propose that the dimensions of consumer VCC are: relational value, personal value, economic value, interactive value, and experiential value. This scale can be used to measure the collaborative value generated in the online value co-creation process. Personal value represents the personal aspects of co-created value, such as the self-esteem, influence, control, and sense of achievement acquired while completing the task. Relational value represents the creation of friendships and connections between customers and businesses, and from customer to customer. Interactive value refers to the value created in interpersonal communication, dialogue, reciprocity, and exchange of ideas and values. Economic value concerns the exchange value of the time, efforts, and money invested by the customer in co-creation. Experiential value denotes the phenomenological aspect of value, in which value is created in the process and results from co-creation. Above all, it is hedonic, memorable, and deeply satisfying in nature. Agrawal \& Rahman (2017) argue that of these five dimensions, it is the interactive and experiential forms that are most important to any value co-creation process.

\section{Consequences of VCC in ecotourism}

Ramaswamy (2008) observe that leading businesses are learning to sustain competitive advantages through the co-creation of experiences of value alongside customers. A central premise of service-dominant logic holds that satisfaction will probably increase when producer and customer co-create the service offering (Lusch \& Vargo, 2006).

As principal consequences, theoretically proposed in the literature, it is worth highlighting customer satisfaction (Agrawal \& Rahman, 2017; Gebauer, Füller, \& Pezzei, 2013; Grissemann \& Stokburger-Sauer, 2012; Grönroos, 2008; Ranjan \& Read, 2016) and loyalty to the business (Grissemann \& Stokburger-Sauer, 2012; Nusair et al., 2013; Rihova et al., 2015) (see Figure 2).

Value co-creation is closely related to customer satisfaction (Agrawal \& Rahman, 2017). Meanwhile, Grissemann \& Stokburger-Sauer (2012) conclude that the level of co-creation increases customer satisfaction. At the same time, these authors also 
consider customer satisfaction with their own co-creation performance, demonstrating that this variable plays a moderating role in the relationship between the level of cocreation and satisfaction with the service provider.

Customer satisfaction with the co-creation performance is understood as satisfaction with their own participation in the creation of a service offering (Grissemann \& Stokburger-Sauer, 2012); as to our object of study, satisfaction with the outcome of consumer assessment or performance is cited as a consequence of VCC on technological platforms. Other authors, such as Gebauer, Füller, \& Pezzei (2013), discuss the pros and cons of online co-creation, observing customer satisfaction or dissatisfaction with their experience and the outcome of co-creation in online communities.

As to the next consequence, loyalty, Grissemann \& Stokburger-Sauer (2012) identify that the degree of co-creation has a positive effect on customer loyalty to service providers, whereby loyalty materializes in the form of revisits and recommendation intentions. Nusair et al. (2013), for their part, argue that travel businesses must establish strong and positive links of social interaction with users to assure trust and loyalty, whereby the latter is key to building long-term marketing relations.

Likewise, Rihova et al. (2015) stress that those tourists who play active and participative roles in co-creation will be more likely to gain satisfaction from their own experiences, and, thus, to be loyal to the organization. In addition, Luo, Zhang, \& Liu (2015) agree that value co-creation practices in virtual communities influence consumer-brand-consumer triad relationships in relation to brand loyalty.

Figure 2 Online ecotourist value co-creation theoretical model

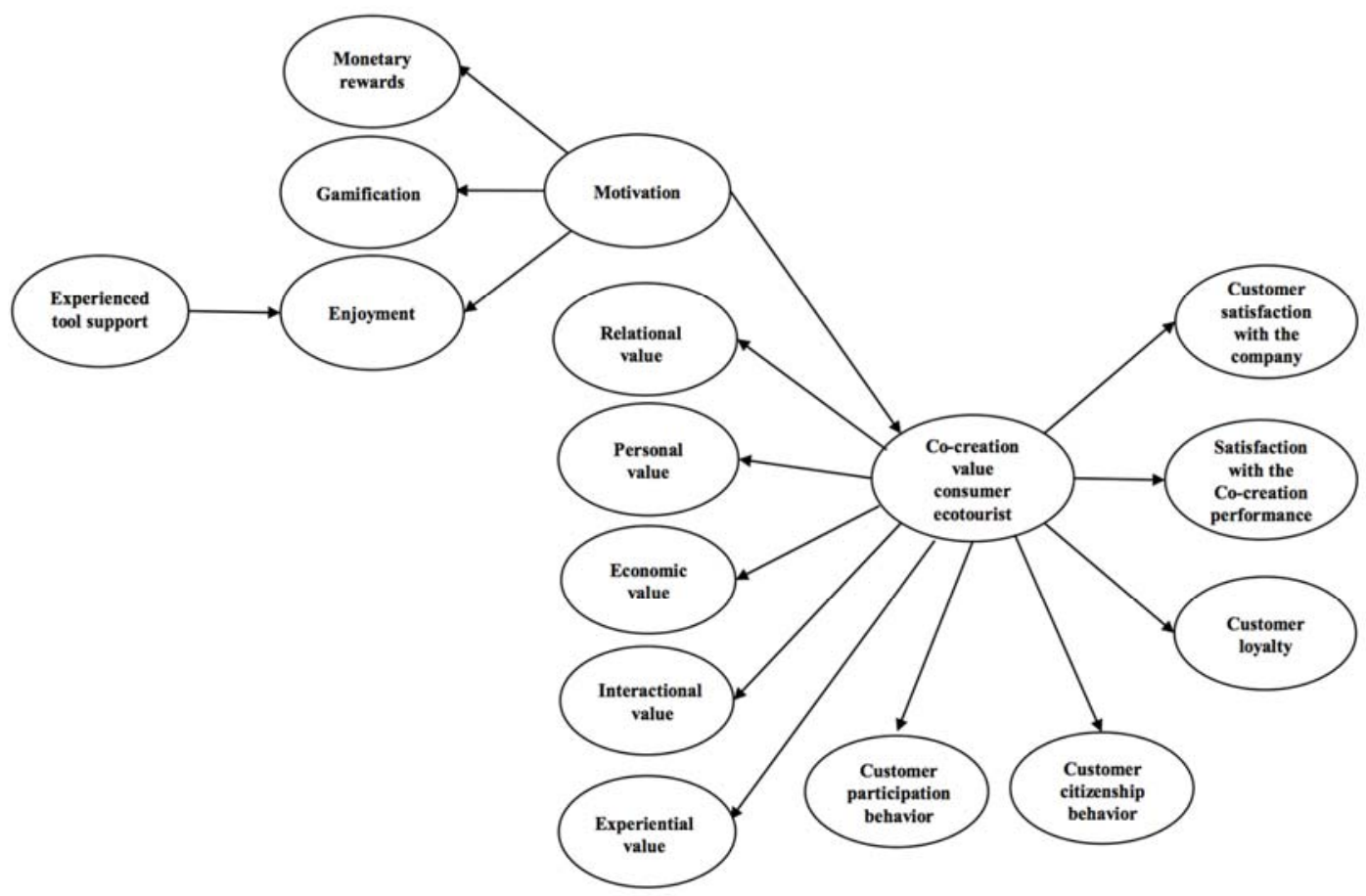

Source: Compiled by authors based on Agrawal \& Rahman (2017); Füller et al. (2010); Grissemann \& Stokburger-Sauer (2012); Yi \& Gong (2013) 
Hernández-López, L. \& Del Barrio-García, S. (2018). Value Co-Creation in Ecotourism: Seeking Joint Solutions in a Digital Era, 2008-2014. Journal of Business, Universidad del Pacífico (Lima, Peru) Vol.10 (1): 38-51

\section{Conclusions}

Tourism constitutes an endless source of experiences, and thanks to technology, tourists have more opportunities than ever before to co-create their own experiences (Binkhorst, 2008). This means creating experiences that correspond to customer needs and interests; moreover, looking specifically at ecotourism, the new trends pose a clear challenge, illustrating the need for a transformation in the sector's business models.

Thus, value co-creation with consumers in ecotourism is particularly important given the experiential nature of the tourist products (Tussyadiah \& Zach, 2013). Providing customers with the opportunity to co-create requires intense customer-customer and customer-business interactions, to say nothing of interactions with other actors. Customers who act as co-developers and promoters can prove highly useful to service companies in ensuring successful marketing strategies (Yang, et al., 2014). Therefore, businesses should incorporate hedonic motivational factors in their marketing strategies to encourage customers to participate in value co-creation in virtual environments. Experts in value co-creation with ecotourism customers need to sustain motivated communities that enjoy the experience of co-creation as a whole, feel part of the project, and use it to obtain high-quality content. Moreover, money rewards are also important in motivating a community.

In addition, there is a need to provide platforms on which ecotourists can co-create with businesses, tour operators, etc., by developing tailored offerings and promoting an environment with multiple options. This will provide opportunities in which to leverage competitive advantages and potential attributes that allow ecotourism destinations to develop new products and services that chime with consumer demand, desires, and engagement. Moreover, providing interactive tools will encourage ecotourism users to participate and collaborate in content generation, while ecotourism organizations will be able to receive opinions, knowledge, desired characteristics, and feedback from customers regarding destinations or ecotourism products and services.

In the future, the most successful destinations will be those that abandon the traditional top-down approach in favor of bottom-up and co-created brand strategies (Oliveira \& Panyik, 2014). As such, this work contributes to the analysis of factors central to online value co-creation in ecotourism by proposing a theoretical model of VCC antecedents and consequences for empirical validation by future research works.

\section{Bibliography}

Agrawal, A. K., \& Rahman, Z. (2015). Roles and Resource Contributions of Customers in Value Co-creation. International Strategic Management Review, 3(1-2), 144-160.

Agrawal, A. K., \& Rahman, Z. (2017). CCV Scale: Development and Validation of Customer Co-Created Value Scale in E-Services. Current Psychology, 1-17.

Amaral, F., Tiago, T., \& Tiago, F. (2014). User-generated content: tourists' profiles on Tripadvisor. International Journal of Strategic Innovative Marketing, 1, 137-147. 
Awuor, F. O., Hayombe, P. O., Ayieko, M. A., \& Agong, S. G. (2015). Experiential value co- creation: what 's the significance of the co-created value to providers ? International Journal of Business and Social Research, 5(10), 1-9.

Bharwani, S., \& Jauhari, V. (2013). An exploratory study of competencies required to co-create memorable customer experiences in the hospitality industry. International Journal of Contemporary Hospitality Management, 25(6), 823-843.

Binkhorst, E. (2008). Turismo de co-creación, valor añadido en escenarios turísticos. Journal of Tourism Research/Revista de Investigacion En Turismo, 1(1), 40-51.

Cabiddu, F., Lui, T. W., \& Piccoli, G. (2013). Managing Value Co-Creation In The Tourism Industry. Annals of Tourism Research, 42, 86-107. https://doi.org/10.1016/j.annals.2013.01.001

Ceballos-Lascurain, H. (1987). The future of ecotourism. Mexico Journal.

Cheung, M. F. Y., \& To, W. M. (2016). Service co-creation in social media: An extension of the theory of planned behavior. Computers in Human Behavior, 65, 260266.

Chuang, H. M., Lin, C. K., Chen, D. R., \& Chen, Y. S. (2013). Evolving MCDM applications using hybrid expert-based ISM and DEMATEL models: An example of sustainable ecotourism. The Scientific World Journal, 2013.

Constantinides, E., Brünink, L. A., \& Romero, C. L. (2015). Customer motives and benefits for participating in online co-creation activities. International Journal of Internet Marketing and Advertising, 9(1), 21.

Cossío-Silva, F. J., Vega-Vázquez, M., \& Revilla-Camacho, M. Á. (2016). La percepción del cliente sobre la co-creación de valor. Adecuación de la escala de Yi y Gong al contexto español. Esic Market Economics and Business Journal, 47(1), 25-40.

Cova, B., \& Salle, R. (2008). Marketing solutions in accordance with the S-D logic: Cocreating value with customer network actors. Industrial Marketing Management, 37(3), 270-277.

Frias Jamilena, D. M., Polo Pena, A. I., \& Rodriguez Molina, M. A. (2016). The Effect of Value-Creation on Consumer-Based Destination Brand Equity. Journal of Travel Research.

Füller, J. (2010). Refining Virtual Co-Creation from a Consumer Perspective. California Management Review, 52(2), 98-122.

Füller, J., Mühlbacher, H., Matzler, K., \& Jawecki, G. (2010). Consumer empowerment through internet-based co-creation. Journal of Management Information Systems, 26(3), 71-102.

Gebauer, J., F??ller, J., \& Pezzei, R. (2013). The dark and the bright side of cocreation: Triggers of member behavior in online innovation communities. Journal of Business Research, 66(9), 1516-1527.

Grissemann, U. S., \& Stokburger-Sauer, N. E. (2012). Customer co-creation of travel services: The role of company support and customer satisfaction with the co-creation performance. Tourism Management, 33(6), 1483-1492. 
Hernández-López, L. \& Del Barrio-García, S. (2018). Value Co-Creation in Ecotourism: Seeking Joint Solutions in a Digital Era, 2008-2014. Journal of Business, Universidad del Pacífico (Lima, Peru) Vol.10 (1): 38-51

Gronroos, C. (2000). Creating a Relationship Dialogue: Communication, Interaction and Value. Marketing Review, 1(1), 5.

Grönroos, C. (2008). Service logic revisited: who creates value? And who co-creates? European Business Review, 20(4), 298-314.

Gummesson, E., \& Mele, C. (2010). Marketing as Value Co-creation Through Network Interaction and Resource Integration. Journal of Business Market Management, 1-18. Hoyer, W. D., Chandy, R., Dorotic, M., Krafft, M., \& Singh, S. S. (2010). Consumer

Cocreation in New Product Development. Journal of Service Research, 13(3), 283296.

Ind, N., \& Coates, N. (2013). The meanings of co-creation. European Business Review, 25(1), 86-95.

Jeong, E., \& Jang, S. S. (2011). Restaurant experiences triggering positive electronic word-of-mouth (eWOM) motivations. International Journal of Hospitality Management, 30(2), 356-366.

Lu, W., \& Stepchenkova, S. (2012). Ecotourism experiences reported online: Classification of satisfaction attributes. Tourism Management, 33(3), 702-712.

Luo, N., Zhang, M., \& Liu, W. (2015). The effects of value co-creation practices on building harmonious brand community and achieving brand loyalty on social media in China. Computers in Human Behavior, 48, 492-499.

Lusch, R., \& Vargo, S. (2006). Service-dominant logic as a foundation for a general theory. The Service-Dominant Logic of Marketing: Dialog, Debate, and Directions.

Mack, C. (2011). Ecotourism, Ethical \& Sustainable Why Are There So Many Terms? Retrieved November 15, 2017, from https://www.responsibletravel.com/holidays/responsible-tourism/travel-

McColl-Kennedy, J. R., Vargo, S. L., Dagger, T. S., Sweeney, J. C., \& Kasteren, Y. v. (2012). Health Care Customer Value Cocreation Practice Styles. Journal of Service Research, 15(4), 370-389.

Neuhofer, B., Buhalis, D., \& Ladkin, A. (2014). A Typology of Technology-Enhanced Tourism Experiences. Tourism, 113(2014), 16(4), 340-350.

Ng, I. C. L., Nudurupati, S. S., \& Tasker, P. (2010). Value Co-Creation in the Delivery of Outcome-Based Contracts for Business-To-Business Services. Business, 1-48.

Nusair, K. K., Bilgihan, A., \& Okumus, F. (2013). The role of online social network travel websites in creating social interaction for gen y travelers. International Journal of Tourism Research, 15(5), 458-472.

O'Connor, P. (2008). User-Generated Content and Travel: A Case Study on Tripadvisor.Com. In Information and Communication Technologies in Tourism 2008 (Vol. 33, pp. 47-58). Vienna: Springer Vienna.

Oliveira, E., \& Panyik, E. (2014). Content, context and co-creation: Digital challenges in destination branding with references to Portugal as a tourist destination. Journal of Vacation Marketing, 21(1), 53-74. 
OMT. (2002). Turismo: Panorama 2020 Volumen 7: Previsiones mundiales y perfiles de los segmentos de mercado. Madrid: Organización Mundial del Turismo. Retrieved from https://www.e-unwto.org/doi/pdf/10.18111/9789284404766

Orcik, A., Tekic, Z., Borocki, J., \& Anisic, Z. (2014). Unused Potential of Co-Creation in South-East Europe: Is it about the Culture? International Conference for Entrepreneurship, Innovation and Regional Development ICEIRD 2014, 13-21.

Piller, F. T., \& Gülpen, C. (2016). Beyond the Offer: Co-creation in Tourism: When Your Guest Becomes Your Partner, Value Emerges, 171-187.

Plé, L., \& Cáceres, R. C. (2010). Not always co-creation: introducing interactional codestruction of value in service-dominant logic. Journal of Services Marketing, 24(6), 430-437.

Prahalad, C. K., \& Ramaswamy, V. (2000). Co-Opting Customer Competence. Harvard Business Review, 78(1), 79-90.

Prahalad, C. K., \& Ramaswamy, V. (2004a). Co-creating unique value with customers. Strategy and Leadership, 32(3), 4-9.

Prahalad, C. K., \& Ramaswamy, V. (2004b). Co-creation experiences: The next practice in value creation. Journal of Interactive Marketing, 18(3), 5-14.

Prebensen, N. K., \& Foss, L. (2011). Coping and co-creating in tourist experiences. International Journal of Tourism Research, 13(1), 54-67.

Prebensen, N. K., Woo, E., \& Uysal, M. S. (2013). Experience value: antecedents and consequences. Current Issues in Tourism, (February 2015), 1-19.

Ramaswamy, V. (2008). Co-creating value through customers' experiences: the Nike case. Strategy and Leadership, 36(5), 9-14.

Ramaswamy, V. (2009). Co-creation of value - towards an expanded paradigm of value creation. Marketing Review St. Gallen, 26(6), 11-17.

Randall, W., Gravier, M., \& Prybutok, V. (2011). Connection, trust, and commitment: dimensions of co-creation? Journal of Strategic Marketing, 19(1), 3-24.

Ranjan, K. R., \& Read, S. (2016). Value co-creation: concept and measurement. Journal of the Academy of Marketing Science, 44(3), 290-315.

Revilla Hernández, M., Santana Talavera, A., \& Parra López, E. (2016). Effects of cocreation in a tourism destination brand image through twitter. Economic Policy, (2116).

Rihova, I, Buhalis, D, Moital, M, and Gouthro, M.-B. (2015). Conceptualising Customerto-customer Value Co-creation in Tourism. Tourism.

Rodríguez, N. G., Álvarez, B. Á., \& Vijande, M. L. S. (2011). Aplicación de la Lógica Dominante del servicio (LDS) en el sector tur??stico: El marketing interno como antecedente de la cultura de co-creaci??n de innovaciones con clientes y empleados. Cuadernos de Gestion, 11(2), 53-75.

Sarkar, S. K., Au, N., \& Law, R. (2015). A study on online actions of ecotourists visiting nature based atractions in Kuala Lumpur. Revista Turismo: estudos e práticas, 4. 
Sarkar, S. K., Au, N., \& Law, R. (2013). Analysing Ecotourists' Satisfaction in Socialisation and Knowledge Sharing Intentions via Social Media. In Information and Communication Technologies in Tourism 2014 (pp. 313-326). Cham: Springer International Publishing.

Sigala, M. (2015). Collaborative commerce in tourism: implications for research and industry. Current Issues in Tourism, 3500(January), 1-10.

Tussyadiah, I., \& Zach, F. (2013). (2013). Social media strategy and capacity for consumer co-creation among destination marketing organizations. Information and Communication Technologies in Tourism, 24-35.

Von Solms, W., \& Von Solms, R. (2016). Co-creation: Tourism , Technology and Wellness, 1-8.

Weaver, D. B., \& Lawton, L. J. (2002). Overnight Ecotourist Market Segmentation in the Gold Coast Hinterland of Australia. Journal of Travel Research, 40(3), 270-280.

Yadav, M., Kamboj, S., \& Rahman, Z. (2016). (2016). Customer co-creation through social media: The case of "Crash the Pepsi IPL 2015." Journal of Direct, Data and Digital Marketing Practice, 17(4), 258-258.

Yang, Chiang, Cheng, H. (2014). Customer Value and Customer Roles on Social Media: A Travel Agency Case Study. International Journal of Business and Information, 9(4), 411-432.

Yi, Y., \& Gong, T. (2013). Customer value co-creation behavior: Scale development and validation. Journal of Business Research, 66(9), 1279-1284.

Yoo, K.-H., Sigala, M., \& Gretzel, U. (2016). Exploring TripAdvisor. In R. Egger, I. Gula, \& D. Walcher (Eds.) (pp. 239-255). Berlin, Heidelberg: Springer Berlin Heidelberg.

Zwass, V. (2010). Co-Creation: Toward a Taxonomy and an Integrated Research Perspective. International Journal of Electronic Commerce, 15(1), 11-48. 